\title{
Ovarian angiogenesis in rabbits: endotheliotrophic chemoattractant activity from isolated follicles and dispersed granulosa cells
}

\author{
J. D. Rone ${ }^{1,2}$, L. M. Halvorson ${ }^{1 *}$ and A. L. Goodman ${ }^{1,2} \dagger$ \\ ${ }^{1}$ Department of Gynecology and Obstetrics, Johns Hopkins University, School of Medicine, Baltimore, \\ MD 21287, USA; and ${ }^{2}$ Department of Physiology and Biophysics, University of Alabama \\ at Birmingham, Birmingham, AL 35294, USA
}

\begin{abstract}
To test the hypothesis that angiogenesis is an important variable in ovarian folliculogenesis, we measured endothelial cell migration (chemotaxis) in media conditioned by rabbit ovarian cells. Endothelial cell migration, a reliable predictor of angiogenesis in vivo, was stimulated by media conditioned by isolated intact follicles $(0.4-2.2 \mathrm{~mm}$ in diameter) from either unstimulated or hCG-stimulated (pseudopregnant) rabbits. In separate experiments, endothelial cell migration was also stimulated by granulosa cell-conditioned media. Follicular chemoattractant activity was associated with a molecular weight greater than 30000 but was not correlated with follicular size or steroid concentrations in the media, although there was no evidence to suggest that the biological activity detected in media conditioned by either intact follicles or dispersed granulosa cells was the same. Demonstration of nonsteroidal chemoattractant activity in media conditioned by intact follicles or by dispersed granulosa cells provides evidence that follicles secrete a vascular chemotactic factor, and is consistent with a role for angiogenesis in follicle growth.
\end{abstract}

\section{Introduction}

Ovarian follicular growth is accompanied by an increase in thecal blood and lymphoid vessels which remain outside the basal lamina until ovulation. Follicular growth is sequential; follicles continue to grow until they either become atretic or ovulate. Differences in local ovarian follicular vasculature may influence follicular growth: some follicles thrive in response to extraovarian factors (i.e. gonadotrophins) provided by an increased blood supply, whereas others may suffer from inadequate support and hence become atretic Jones, 1978; Moor and Seamark, 1986).

Since differential access to blood-borne extraovarian factors may explain why some follicles continue to grow and mature while others become atretic, growing follicles may secrete a factor(s) that induces local angiogenesis (neovascularization). To date, potential ovarian angiogenic factors include fibroblast growth factor (Gospodarowicz et al., 1985; Neufeld et al., 1987), epidermal growth factor (Skinner et al., 1987) and a heparinbinding vascular endothelial growth factor (Phillips et al., 1990).

To provide data relevant to the participation of an ovarian angiogenic factor in the regulation of follicular growth, we examined the effect of media conditioned by either intact rabbit follicles or dispersed granulosa cells on endothelial cell migration. Vascular endothelial cell migration is an integral part of new blood vessel formation and cell migration in vitro

*Present address: Department of Gynecology and Obstetrics, Beth Israel Hospital, Boston, MA 02215, USA.

†Present address: The Jones Institute for Reproductive Medicine, Department of Obstetrics and Gynecology, Eastern Virginia Medical School, Norfolk, VA 23507, USA.

Received 18 March 1992 (chemotaxis) correlates closely with angiogenesis in vivo (Folkman, 1984). The purpose of this study was therefore to determine (i) whether rabbit follicles produce potential angiogenic factors; (ii) whether follicular production of angiogenic factor(s) is related to follicular size, health or steroidogenesis and (iii) whether follicular production of angiogenic factor(s) is influenced by gonadotrophins.

\section{Materials and Methods}

\section{Animals}

New Zealand White virgin female rabbits $(3-5 \mathrm{~kg})$ were obtained from local suppliers, and housed in air conditioned quarters with a $12 \mathrm{~h}$ lighting schedule. Food and water were available ad libitum. Rabbits were caged individually at least three weeks before any experiment. Both unstimulated and hCG-stimulated (pseudopregnant) rabbits were used. Pseudopregnancy was induced by i.v. injection of hCG (62.5 iu per doe) (Sigma, St Louis, MO); day of injection is day 0 of pseudopregnancy (which lasts approximately 18 days in the rabbit). In hCG-stimulated (pseudopregnant) rabbits, ovaries were removed on day 3, day 5 or day 7 of pseudopregnancy. Animals were killed by decapitation in a guillotine or by rapid i.v. injection of a lethal dose of sodium pentobarbitone.

\section{Reagents}

Powdered media and supplements, fetal bovine serum (FBS), and calf serum were obtained from Sigma or Gibco (Grand 
Island, NY). Media and supplements were reconstituted in deionized water (Nanopure, Barnstead, Rochester, NY), and sterile filtered $(0.2 \mu \mathrm{m}$ Sterivex filters, Millipore Corp., Bedford, MA) before use. Collagenase type CLS (168 $\mathrm{U} \mathrm{mg}^{-1}$ ) was purchased from Cooper Biomedical (Malvern, PA); bovine serum albumin (BSA, Fraction V) was purchased from Sigma. Ovine luteinizing hormone (NIADDK-oLH-25) and ovine follicle stimulating hormone (NIH-oFSH-13) were obtained from the National Hormone and Pituitary Program, Baltimore, MD. Stock solutions of ovine $\mathrm{LH}\left(200 \mu \mathrm{g} \mathrm{ml}^{-1}\right)$ and ovine FSH $\left(100 \mu \mathrm{g} \mathrm{ml}^{-1}\right)$ were kept frozen $\left(-20^{\circ} \mathrm{C}\right)$ in sterile aliquots in Dulbecco's Modified Eagle Medium (DME) plus $0.1 \%$ BSA until used.

\section{Follicular culture}

Each pair of ovaries was removed, using aseptic technique, placed in DME (supplemented with $25 \mathrm{mmol}$ Hepes $\mathrm{I}^{-1}$ and $100 \mathrm{iu}$ penicillin $\mathrm{ml}^{-1}$ and $100 \mu \mathrm{g}$ streptomycin $\mathrm{ml}^{-1}$ ) and trimmed of extraneous tissue. Follicles were mechanically dissected using no. 5 watchmaker forceps under a stereomicroscope $($ at $\times 10)$. Follicular diameter was measured via calibrated ocular reticle, and follicles were transferred to holding dishes containing similarly sized follicles. When the dissection of each ovary was completed, individual follicles were transferred to separate wells of 24 or 96 well plates (Falcon, Becton Dickinson and Co., Lincoln Park, NJ) containing 0.5 or $0.2 \mathrm{ml}$ of incubation media per well, respectively, and cultured at $37^{\circ} \mathrm{C}$ in a $\mathrm{CO}_{2}$ incubator. Conditioned media were collected after $24 \mathrm{~h}$ and stored in $12 \times 75 \mathrm{~mm}$ glass culture tubes (VWR Scientific, Bridgeport, NJ) at $-20^{\circ} \mathrm{C}$ until assayed; aliquots of identical unconditioned control media were stored in the same way.

Incubation media were either Ham's F12 plus insulin $(5 \mu \mathrm{g}$ $\mathrm{ml}^{-1}$ ), transferrin $\left(5 \mu \mathrm{g} \mathrm{ml} \mathrm{g}^{-1}\right.$ ), and selenium ( $5 \mathrm{ng} \mathrm{ml}^{-1}$ ) (ITS; Collaborative Research or Sigma) or Ham's F12 plus $0.5 \%$ FBS plus ITS. Ascorbic acid $\left(50 \mu \mathrm{g} \mathrm{ml}^{-1}\right)$ and glutamine $\left(2 \mathrm{mmol} \mathrm{I}^{-1}\right)$ were routinely added to all incubation media. Oestradiol, testosterone and progesterone concentrations in unextracted follicular-conditioned media (diluted 1:10-1:100) were measured by established radioimmunoassay (RIA) procedures (Goodman and Hodgen, 1982), previously validated for culture media (Goodman, 1984).

\section{Granulosa cell culture}

Granulosa cell-conditioned media were obtained by trimming fat from ovaries (from ten rabbits in four separate experiments) and rinsing in DME. Under a stereomicroscope, three to eight follicles per ovary of surface diameter $0.3-0.9 \mathrm{~mm}$ were punctured with a sterile 30 -gauge needle held on a $1 \mathrm{ml}$ tuberculin syringe, which was also used to dislodge mural granulosa cells (Goodman, 1984). Media containing cells were pooled, centrifuged at $100 \mathrm{~g}$ for $10 \mathrm{~min}$ and the cells were resuspended in DME. An aliquot was removed to estimate cell concentration (haemocytometer) and cell viability (trypan blue exclusion). Initial viability was $20-25 \%$. Granulosa cells were plated in $10 \%$ FBS DME; after $24 \mathrm{~h}$, media were replaced with $0.5 \% \mathrm{FBS}$ DME with and without hormones. In two experiments, granulosa cells were plated at 50000 viable cells $\mathrm{cm}^{-2}$; media contained either no hormone, $100 \mathrm{ng} \mathrm{LH} \mathrm{ml}^{-1}, 100 \mathrm{ng} \mathrm{FSH} \mathrm{ml}^{-1}$, or $100 \mathrm{ng} \mathrm{LH} \mathrm{ml} \mathrm{m}^{-1}$ plus $100 \mathrm{ng} \mathrm{FSH} \mathrm{ml} \mathrm{m}^{-1}$. In two additional experiments, granulosa cells were plated at varying densities from 2500 to 40000 viable cells $\mathrm{cm}^{-2}$ and media contained either $0,10,30,90 \mathrm{ng} \mathrm{LH} \mathrm{ml} l^{-1}$, or 0 or $90 \mathrm{ng} \mathrm{FSH} \mathrm{ml}^{-1}$ at 40000 viable cells $\mathrm{cm}^{-2}$. Granulosa cell-conditioned media and identical unconditioned media were collected after 24,48 and $72 \mathrm{~h}$ in culture at $37^{\circ} \mathrm{C}$ in a $\mathrm{CO}_{2}$ incubator, centrifuged at $1500 \mathrm{~g}$ for $20 \mathrm{~min}$ to remove cellular debris and particulate matter, then stored at $-20^{\circ} \mathrm{C}$ until bioassayed.

\section{Cell migration assays}

Endothelial cells were isolated from rabbit thoracic aorta or rabbit abdominal fat pads and characterized on the basis of morphological and immunocytological (presence of angiotensinconverting enzyme) criteria (Goodman and Rone, 1987; Rone and Goodman, 1987). Endothelial cells were used in the chemotaxis bioassay between the third and ninth passage.

Cell migration assays were conducted in 48-microwell modified Boyden chamber assemblies (Neuroprobe, Cabin John, MD) using $8 \mu \mathrm{m}$ pore polycarbonate membranes (Neuroprobe; PVPfree) as previously described (Goodman and Rone, 1987; Rone and Goodman, 1990). The number of migrated cells $\mathrm{mm}^{-2}$ in $2 \mathrm{~h}$ was determined for each well; each test and control medium (conditioned versus unconditioned medium) was assayed in triplicate on the same membrane.

\section{Statistical analysis}

Statistical significance of differences between test and control media was estimated by one-way analysis of variance and by Student's $t$ tests, using the mean square error term from the analysis of variance (Goodman and Rone, 1987); comparisons of several treatments with one control were performed according to Dunnett's procedure (Dunnett, 1964). Conditioned media were considered to contain chemoattractant activity when it produced a statistically significant increase in cell migration $(P<0.05)$ versus otherwise identical unconditioned media. The coefficient of variation of triplicate determinations ranged from 4 to $20 \%$; because the number of migrated cells $\mathrm{mm}^{-2}$ membrane is Poisson distributed, percentage error was lower at higher migration rates (Goodman and Rone, 1987).

\section{Ultrafiltration}

To begin characterization of the angiogenic factor, conditioned media containing significant chemoattractant activity were combined for ultrafiltration and reversed-phase chromatography. Rabbit follicular-conditioned media, rabbit granulosa cell-conditioned media, and identical unconditioned media were fractionated and concentrated using 10 and $30 \mathrm{kDa}$ cutoff (MWCO) ultrafilters (Centricon, Amicon Corp., Danvers, MA) according to manufacturer's instructions. Retentates were diluted in Dulbecco's phosphate-buffered saline containing $\mathrm{Ca}^{2+}$ and $\mathrm{Mg}^{2+}$ to an even multiple or fraction of the starting volume of unfractionated media before assay (Goodman and Rone, 1987). Both filtrate and retentate were bioassayed for chemoattractant activity. 
Table 1. Steroid accumulation and chemoattractant activity in media conditioned by isolated follicles from three rabbits in oestrus

\begin{tabular}{lcccc}
\hline $\begin{array}{l}\text { Follicle diameter } \\
(\mathrm{mm})\end{array}$ & $\begin{array}{c}\text { Oestradiol } \\
\left(\mathrm{pg} \mathrm{ml}^{-1} \text { in } 24 \mathrm{~h}\right)\end{array}$ & $\begin{array}{c}\text { Progesterone } \\
\left(\mathrm{ng} \mathrm{ml}^{-1} \text { in } 24 \mathrm{~h}\right)\end{array}$ & $\begin{array}{c}\text { Testosterone } \\
\left(\mathrm{ng} \mathrm{ml}^{-1} \text { in 24 h) }\right.\end{array}$ & Chemotaxis $^{\mathrm{a}}$ \\
\hline 1.14 & 488 & 1.79 & 0.85 & + \\
1.23 & 3331 & 2.51 & 2.52 & + \\
1.42 & 2625 & $<1.7$ & 4.31 & + \\
1.14 & 2279 & $<1.7$ & 3.46 & + \\
1.33 & 2329 & 2.10 & 1.17 & + \\
1.14 & 212 & $<1.7$ & 3.29 & + \\
1.14 & 58 & 3.87 & 1.67 & - \\
0.95 & $<20$ & $<1.7$ & 0.94 & - \\
1.33 & 4462 & $<1.7$ & 3.01 & - \\
0.95 & 54 & $<1.7$ & 0.65 & - \\
0.95 & 115 & $<1.7$ & 0.77 & \\
\hline
\end{tabular}

${ }^{a}+$ indicates significant $(P<0.05)$ stimulation of endothelial cell migration compared with migration in identical unconditioned media.

\section{Reversed-phase chromatography (steroid extraction)}

Chemoattractant activity was determined in unfractionated follicular-conditioned media, in the $30 \mathrm{kDa}$ retentate of follicularconditioned media and in identically treated unconditioned media (Ham's F12 plus $0.5 \%$ serum plus ITS) after reversedphase chromatography (extraction) on Baker $\mathrm{C}_{18}$ minicolumns according to manufacturer's instructions (J.T. Baker, Phillipsburg, NJ).

\section{Follicular morphology}

Intact follicles, dissected from ovaries at oestrus or day 7 pseudopregnant rabbits, were cultured fully submerged $\left(37^{\circ} \mathrm{C}\right.$ in a $\mathrm{CO}_{2}$ incubator) in Ham's F12 for 1 day. After culture, follicles were fixed overnight in Bouin's fluid and processed for standard paraffin embedding; conditioned media were assayed for endotheliotrophic chemoattractant activity. Serial sections, $7 \mu \mathrm{m}$, stained with haematoxylin and eosin were examined by an observer unaware of follicular-derived chemoattractant activity.

\section{Results}

\section{Chemoattractant activity in intact follicular-conditioned media}

Media conditioned by intact individual follicles $(0.4-2.2 \mathrm{~mm}$ in diameter) were collected from 14 unstimulated rabbits and 11 pseudopregnant rabbits and examined in the chemotaxis bioassay. Endotheliotrophic (chemoattractant) activity was detected in media conditioned by $45 \%$ of the follicles $(n=530)$ recovered from unstimulated rabbits and in $21 \%$ of the follicles $(n=146)$ recovered from pseudopregnant rabbits relative to identical unconditioned media bioassayed on the same membrane. Sixty per cent $(n=319)$ of all follicles examined from unstimulated rabbits ranged in size from 0.7 to $1.0 \mathrm{~mm}$; of these, endotheliotrophic activity was detected in $144(27 \%)$ of the follicles bioassayed.
Intact individual follicles were collected from nine day 7 pseudopregnant rabbits, and from one day 3 and one day 5 pseudopregnant rabbit. Thirty-nine (27\%) of the total follicles collected from pseudopregnant rabbits were $0.8-1.0 \mathrm{~mm}$ in diameter; endotheliotrophic activity was detected in media conditioned by three of those follicles. Twenty per cent $(n=29)$ of all follicles bioassayed from pseudopregnant rabbits were $1.4 \mathrm{~mm}$ in diameter; of these, 11 (7.5\%) of the follicles bioassayed demonstrated endotheliotrophic activity.

Chemoattractant activity in media conditioned by intact follicles from either unstimulated or pseudopregnant rabbits was not related to follicular size or steroid concentration (Table 1). To determine whether follicular-derived chemoattractant activity was steroidal, conditioned media were assayed after fractionation by reversed-phase $\mathrm{C}_{18}$ minicolumns (which removes $>95 \%$ of steroids; Redmer et al., 1985a). Follicularconditioned media were compared to identical unconditioned media subjected to the same treatment in parallel, as discussed in the Methods section.

Endotheliotrophic activity was not removed by reversedphase chromatography (123 \pm 15 , follicular-conditioned media before extraction versus $61 \pm 15$ cells $\mathrm{mm}^{-2}$ in $2 \mathrm{~h}$, identical unconditioned media before extraction; $168 \pm 7$, follicularconditioned media after extraction versus $98 \pm 6$ cells $\mathrm{mm}^{-2}$ in $2 \mathrm{~h}$, identical unconditioned media after extraction, $P<0.01$ ). Chemoattractant activity in follicular-conditioned media was retained by 30000 MWCO ultrafilters and by ultrafiltration after extraction (Table 2). Chemoattractant activity was detected after ultrafiltration and extraction, but there was not enough material for serial dilutions of either ultrafiltered or extracted samples.

\section{Chemoattractant activity in granulosa cell conditioned media}

Endothelial cell migration was significantly stimulated by granulosa cell-conditioned media (Fig. 1). Endotheliotrophic activity varied directly with the number of granulosa cells per well; however, addition of gonadotrophins to the culture media 
Table 2. Chemoattractant activity after fractionation of rabbit follicular conditioned media by reversed phase chromatography and ultrafiltration

\begin{tabular}{|c|c|c|}
\hline \multirow[b]{2}{*}{ Treatment } & \multicolumn{2}{|c|}{ Rabbit follicular } \\
\hline & $\begin{array}{l}\text { Conditioned } \\
\text { media }^{a}\end{array}$ & $\begin{array}{l}\text { Unconditioned } \\
\text { media }^{\mathrm{a}}\end{array}$ \\
\hline None & $81 \pm 3$ & $23 \pm 3^{*}$ \\
\hline $\begin{array}{l}\text { Reversed phase } \\
\text { chromatography }\end{array}$ & $93 \pm 9$ & $40 \pm 10^{*}$ \\
\hline $\begin{array}{l}\text { Centricon } 30 \\
\text { retentate } \\
\text { filtrate }\end{array}$ & $\begin{array}{l}79 \pm 7 \\
41 \pm 2\end{array}$ & $\begin{array}{l}31 \pm 1^{*} \\
74 \pm 10\end{array}$ \\
\hline $\begin{array}{l}\text { Centricon } 30 \text { after } \\
\text { chromatography } \\
\text { retentate } \\
\text { filtrate }\end{array}$ & $\begin{array}{l}88 \pm 13 \\
78 \pm 10\end{array}$ & $\begin{array}{l}36 \pm 8^{*} \\
72 \pm 8\end{array}$ \\
\hline
\end{tabular}

a Values are expressed as the number of migrated aortic cells $\mathrm{mm}^{-2}$ in $2 \mathrm{~h}$.

${ }^{*} P<0.01$, conditioned versus unconditioned media.

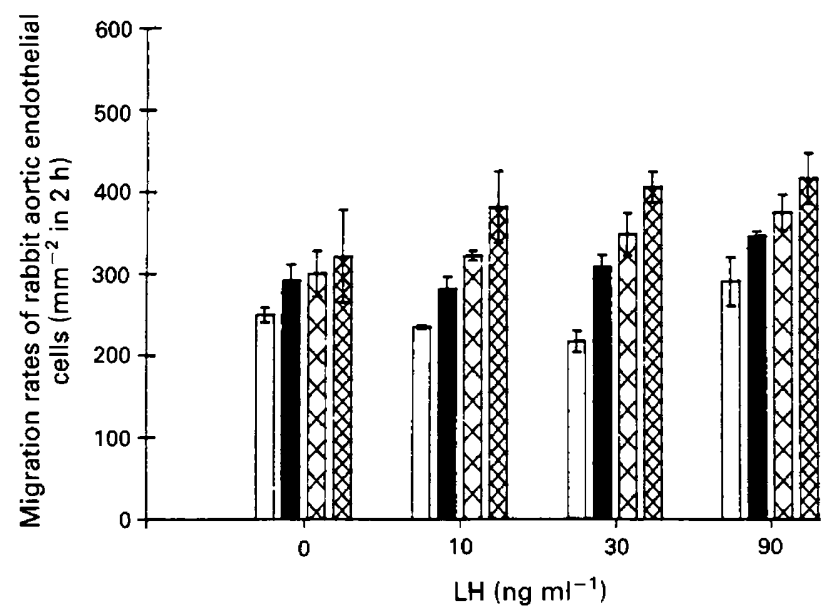

Fig. 1. Comparison of migration rates of rabbit aortic-derived endothelial cells in response to rabbit granulosa cell-conditioned media containing $0,10,30$ or $90 \mathrm{ng} \mathrm{LH} \mathrm{ml}^{-1}$. Granulosa cells from three rabbits were pooled and plated at $O(\square), 2500(\square), 10000(\bigotimes)$ or 40000 ( viable cells $\mathrm{cm}^{-2}$ in Dulbecco's Modified Eagle Medium (DME) containing 10\% fetal bovine serum (FBS); after $24 \mathrm{~h}$, media were replaced with $0.5 \%$ FBS in DME with or without LH and collected after an additional $48 \mathrm{~h}$. Each point represents the mean \pm SEM of triplicate determinations in the chemotaxis bioassay.

did not significantly affect chemoattractant activity (Fig. 1; FSH data are not shown).

Chemoattractant activity was detected in both the 10000 and $30000 \mathrm{MWCO}$ retentates of granulosa cell-conditioned media. Furthermore, serially diluted Centricon 10 retentates produced dose-dependent decreases in endothelial cell migration rates (Fig. 2). Even though there appears to be activity in the $10000 \mathrm{MWCO}$ filtrate, compared with identically treated unconditioned media, there was no difference $(P>0.05)$ between the conditioned and unconditioned filtrate (132 \pm 14 versus $112 \pm 7$ cells $\mathrm{mm}^{-2}$ in $2 \mathrm{~h}$ ).

\section{Morphology}

To relate follicular structure and angiogenic activity individual follicles $(0.8-1.0 \mathrm{~mm})$ were fixed and stained after 1 day in culture. Angiogenically active follicles (chemotaxis bioassay) had a well developed thecal layer, which was preserved in culture (Fig. 3). In contrast, granulosa cells were largely necrotic and there was no evidence of luteinization. Media conditioned by comparably sized wedges of ovarian cortex, containing structurally well preserved admixtures of germinal epithelium, stroma, primordial and preantral follicles and interstitial cell patches, were inactive in the angiogenesis bioassay.

\section{Discussion}

Conditioned media from intact individual follicles and media conditioned by dispersed granulosa cells contained an activity that stimulated endothelial cell migration; stimulation of endothelial cell migration in vitro is considered a reliable predictor of angiogenic activity in vivo (Folkman, 1984). These data support the hypotheses that follicles secrete angiogenic factors and that differential access to blood-borne factors contributes to follicular selection, further growth and development of ovarian follicles or to both (Jones, 1978; Moor and Seamark, 1986). Differential access may be regulated by follicular production of angiogenic factors as well as by other paracrine factors. Differences in local ovarian angiogenesis might account for differences in follicular growth: some follicles thrive in response to an increased blood supply and others suffer from inadequate support and hence become atretic. Preovulatory follicles may emerge because of increased vascular supply; increased vascularization of the dominant follicle of monkeys results in preferential uptake of gonadotrophins (Zeleznik et al., 1981).

In the study reported here, chemoattractant activity was unequivocally detected in media conditioned by some isolated, intact, individual follicles from both unstimulated and hCGstimulated rabbits. In addition, endotheliotrophic activity was detected in media conditioned by dispersed granulosa cells from unstimulated rabbits; this activity was dependent upon the density of granulosa cells in culture. However, we have no evidence to indicate that the biochemical factor(s) producing chemoattractant activity in media conditioned by intact follicles is (are) the same as the factor(s) responsible for chemoattractant activity in media conditioned by dispersed granulosa cells. Chemoattractant activity in granulosa cell-conditioned media may be the result of luteinization; there is considerable evidence demonstrating luteal-derived angiogenic activity (Gospodarowicz et al., 1985; Redmer et al., 1985a, 1988; Phillips et al., 1990; Rone and Goodman, 1990).

In the study reported here, chemoattractant activity in ovarian-conditioned media was associated with a nonsteroidal fraction of molecular mass $>30 \mathrm{kDa}$. A nonsteroidal angiogenic activity $(45-60 \mathrm{kDa})$ has also been detected in human follicular fluid (Frederick et al., 1985). In addition, our laboratory has reported nonsteroidal chemoattractant activity derived 
<smiles>[CH]1[CH]CC[CH]1</smiles>

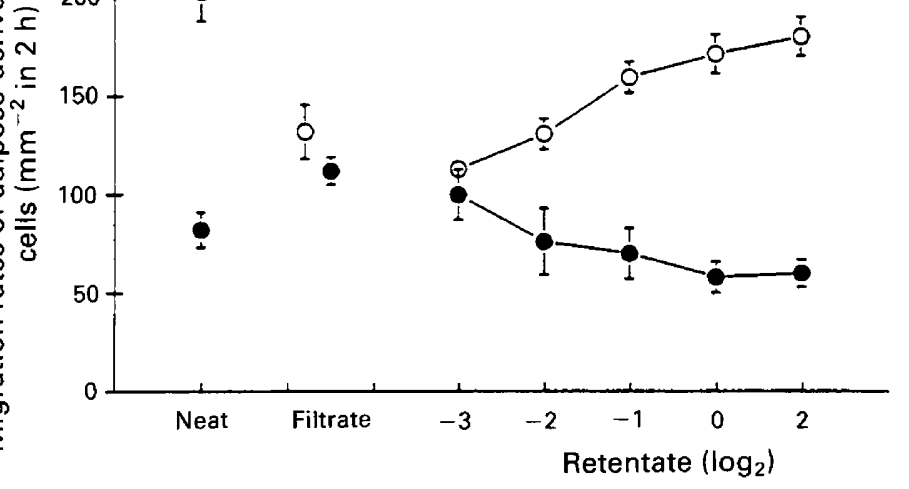

Fig. 2. Comparison of migration rates of rabbit adipose-derived endothelial cells in response to unfractionated (neat) and to serially diluted retentates of rabbit granulosa cell-conditioned media $(O)$ and to identical unconditioned media (-), using Centricon 10 ultrafilters. Retentate $\left(\log _{2}\right)$ is a relative concentration, which is the inverse of the dilution. Each point represents the mean \pm SEM of triplicate determinations in the chemotaxis bioassay. Granulosa cells were obtained from two rabbits and plated at 50000 viable cells $\mathrm{cm}^{-2}$. Rabbit granulosa cell-conditioned media (10\% FBS DME; $2 \mathrm{ml}$ ) were pooled for assay; the conditioned media were taken from dispersed granulosa cells after 24 and $48 \mathrm{~h}$ in culture.

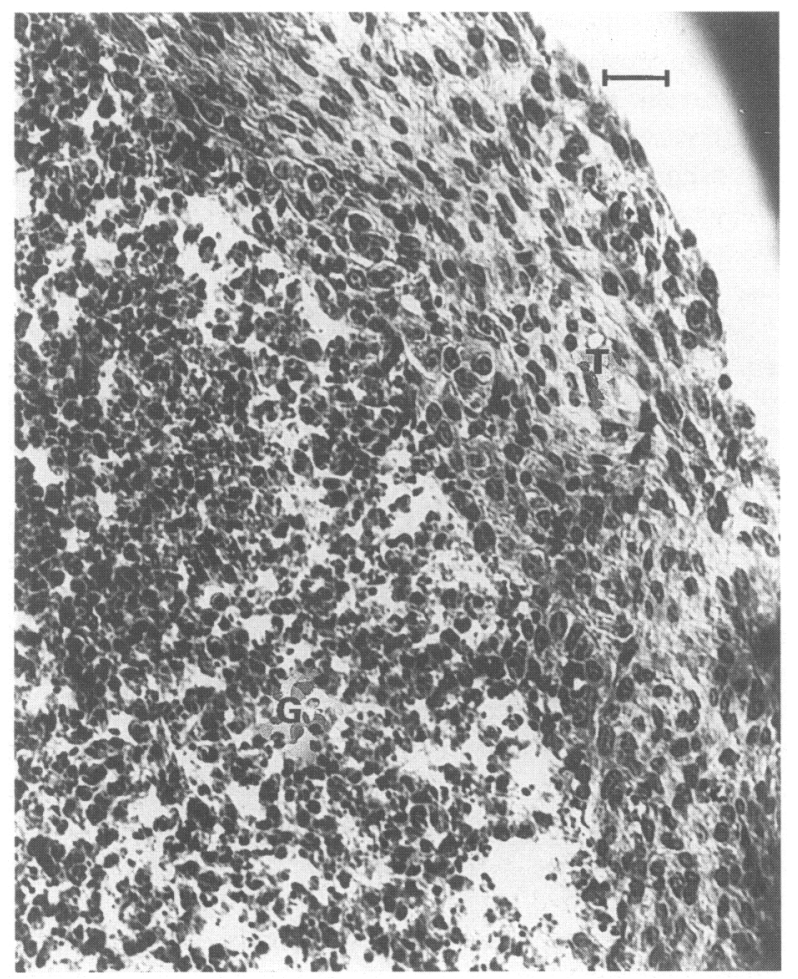

Fig. 3. Light microscopy of an intact rabbit follicle cultured for $24 \mathrm{~h}$, then fixed and stained in haematoxylin and eosin; follicle conditioned media was active in chemotaxis bioassay. T: theca; G: granulosa. Bar: $50 \mu \mathrm{m}$. from rat corpora lutea (nominal molecular mass $20-30 \mathrm{kDa}$ ) that is distinct from fibroblast growth factor (Rone and Goodman, 1990). Rat luteal-derived chemoattractant activity does not depend on the addition of gonadotrophins to the culture media, which is in agreement with our present findings in rabbits. Follicular chemoattractant activity was not associated with steroid secretion, unlike epidermal growth factor and transforming growth factor (Caubo et al., 1989), nor is detection of chemoattractant activity affected by the addition of steroids to unconditioned media (Goodman and Rone, 1987). Although follicular size and steroid secretion are both considered indices of follicular health, we found no evidence to link angiogenesis and steroidogenesis directly in rabbits.

Well-developed theca, as assessed histologically in our study, coincided with significant chemoattractant activity from the intact rabbit follicle. The establishment of the vascular sheath within the theca coincides with the period of rapid growth and differentiation of the follicle (Burr et al., 1951; Richards, 1980). Isolated theca from monkeys stimulate chemotaxis (Redmer et al., 1985b); isolated theca from ovine (Taraska et al., 1989), bovine (Redmer et al., 1991) and porcine (Makris et al., 1984) follicles stimulate mitogenesis. Endothelial cell migration in response to a stimulus (chemotaxis) and mitogenesis of endothelial cells behind the front of migrating cells are two of the principal components of neovascularization (Folkman, 1984). Expression of chemoattractant activity may precede endothelial cell mitogenesis and vascular growth of a differentiating follicle.

Because the rabbit is a reflex ovulator, it does not have a spontaneous ovarian cycle with distinct follicular and luteal phases; follicles grow and are steroidogenically active even after 
ovulation (Osteen and Mills, 1980). Continuous development of follicles in the rabbit could account for the detection of follicular chemoattractant activity from both the unstimulated and hCG-stimulated (pseudopregnant) rabbit. Fewer follicles from pseudopregnant animals had detectable chemoattractant activity compared with unstimulated does, perhaps because we were unable to obtain as many follicles from these animals during early pseudopregnancy. The rabbit ovary is temporarily depleted of the largest follicles following ovulation (Asami, 1920; Osteen and Mills, 1980; Kranzfelder et al., 1984; Setty and Mills, 1987). Alternatively, because the attraction and capture of a blood supply is an early event in follicular development, it is possible that follicles may not continuously secrete a chemotactic substance.

Stimulation of endothelial cell migration by rabbit granulosa cell-conditioned media did not depend on the presence of $\mathrm{LH}$ or FSH in the media. Similar findings have been reported in rats (Koos, 1986) and women (Katz et al., 1992). In addition, granulosa cell-conditioned media from rats treated with pregnant mares' serum gonadotrophin has a mitogenic effect on bovine granulosa cells (Koos and LeMaire, 1983) that was independent of gonadotrophin treatment. If angiogenesis is analogous to the blood coagulation cascade, i.e. one step leading to the next through the action of specific mediators (Findlay, 1986), it is not surprising that chemoattractant activity is not directly dependent upon gonadotrophin treatment. More than one mediator may be responsible for the release of angiogenic activities from the follicle, that is the mitogenic activity of epidermal growth factor is potentiated by ovarian glycosaminoglycans (Sato et al., 1991). There may be additional activities of lower molecular mass (i.e. epidermal growth factor, leukotrienes) released by growing follicles, which cannot be detected in our bioassay.

Thecal and granulosa cells may both secrete angiogenic activity(s), but not necessarily at the same time. The electrophoretic profiles of proteins secreted by human theca and granulosa cells of the dominant follicle in culture appear to be distinct (Lobb and Dorrington, 1987). Angiogenic activity in ovine granulosa cell-conditioned medium is detected only when endogenous $\mathrm{LH}$ is increased, unlike thecal-associated angiogenic activity (Taraska et al., 1989). Similarly, granulosa cells of primate dominant follicles release chemoattractant activity only when cultured with LH and FSH; however, media conditioned by theca of primate dominant follicles contain angiogenic activity independent of gonadotrophin treatment (Redmer et al., 1985b). Extracts of porcine theca but not of porcine granulosa cells stimulate mitogenesis (Makris et al., 1984). In the rabbit follicle, granulosa and endothelial cell proliferation are closely correlated only after hCG stimulus (Kranzfelder et al., 1984). Thus thecal secretion of angiogenic activity may continue throughout antral follicular growth and development, whereas granulosa cells may not express angiogenic activity until just before ovulation (Taraska et al., 1989). Granulosa-derived angiogenic activity after gonadotrophin stimulus may enhance production of thecal angiogenic activity. More chemoattractant activity is released after co-culture of granulosa and theca from monkey dominant follicles than from theca cultured alone (Redmer et al., 1985b). Granulosa angiogenic activity may also maintain preovulatory follicles in a nonatretic state after thecalderived activity has contributed to early follicular selection (Taraska et al., 1989).
Since many of the studies demonstrating endotheliotrophic activity obtain granulosa cells from gonadotrophin-stimulated women (Katz et al., 1992), rats (Koos, 1986) or mice (Sato et al., 1982), there may be a species difference with regard to production of angiogenic activity and gonadotrophin dependence. In contrast to animals with cyclic gonadotrophin release, rabbits continuously produce growing follicles that will become atretic if ovulation is not stimulated by coitus; in the theca of growing and mature rabbit follicles, the number of capillaries increases linearly with increasing follicle size, with no difference between intact and less advanced atretic follicles (Kranzfelder et al., 1984). However, in sheep and pigs, there is a reduction in the inner (but not the outer) wreath of thecal capillaries in atretic follicles (Cran et al., 1983). In rabbits, there is continuous development of follicles irrespective of stage of sexual cycle (Asami, 1920); injection of hCG into pregnant (Adams, 1968; Mills and Gerardot, 1984) rabbits will lead to ovulation. Thus granulosa cells from rabbits may secrete angiogenic activity before gonadotrophin stimulus, whereas granulosa cells from other species may be more dependent on gonadotrophins. Alternatively, granulosa cells in culture may release endotheliotrophic activity characteristic of the luteinization process, which may not be biochemically identical to chemoattractant activity associated with the growing follicle.

These novel studies in rabbits, in addition to our work with primate and rodent ovaries (Redmer et al., 1985a, b; Rone and Goodman, 1990; Katz et al., 1992), support the concept that angiogenesis factor(s) are involved in the paracrine regulation of ovarian cyclic structures. Demonstrations of endotheliotrophic activity in ovarian-conditioned media provide evidence to support the differential access hypothesis. That is, the participation of an ovarian-derived angiogenic substance may act in a paracrine fashion on local endothelial cells and contribute to regulation of the follicle by regulating access to blood-borne factors. Production and release of ovarian factors that stimulate development of local vasculature is a complex process that requires further investigation.

This work was presented in part at the 18th Annual Meeting of the Society for the Study of Reproduction, Montreal, Quebec, Canada, 1985, Abstract no. 498; at the Sixth Biennial Ovarian Workshop, Ithaca, NY, USA, 1986 and at the 20th Annual Meeting of the Society for the Study of Reproduction, Urbana, IL, USA, Abstract no. 127, 1987 and was supported in part by NIH grants HD-17171 and HD-22202.

We would like to express our appreciation to S. Atlas for editorial assistance, to F. Karas for excellent secretarial assistance, to B. Welty for photographic advice, to C. Appling (Birmingham, AL) for steroid RIAs; to P.R.B. Caldwell for generously supplying goat anti-rabbit angiotensin-converting enzyme antiserum and to the National Pituitary Agency for providing the oLH and oFSH used in some of the experiments.

\section{References}

Adams CE (1968) Ovarian response to human chorionic gonadotrophin and egg transport in the pregnant and post-parturient rabbit Journal of Endocrinology $40101-105$

Asami G (1920) Observations on the follicular atresia in the rabbit ovary Anatomical Record 18 323-343

Burr Jr, JH and Davies JI (1951) The vascular system of the rabbit ovary and its relationship to ovulation Anatomical Record $111273-297$ 
Caubo B, DeVinna RS and Tonetta SA (1989) Regulation of steroidogenesis in cultured porcine theca cells by growth factors Endocrinology 125 321-326

Cran DG, Osborn JC and Rushton D (1983) Thecal vasculature and oocyte maturation during follicular atresia in the sheep and pig Reproduction, Nutrition, Development 23 285-292

Dunnett CW (1964) New tables for multiple comparisons with a control Biometrics 20 482-491

Findlay JK (1986) Angiogenesis in reproductive tissue Journal of Endocrinology $111357-366$

Folkman J (1984) Angiogenesis In Biology of Endothelial Cells pp 412-428 Ed. EA Jaffe. Martinus Nijhoff, Boston

Frederick JL, Hoa N, Preston DS, Frederick JJ, Campeau JD, Ono $\mathrm{T}$ and DiZerega GS (1985) Initiation of angiogenesis by porcine follicular fluid American Joumal of Obstetrics and Gynecology 152 1073-1078

Goodman AL (1984) In vitro evidence of a role for inhibin in female rabbits American Joumal of Physiology 246 E243-E248

Goodman AL and Hodgen GD (1982) Antifolliculogenic action of progesterone despite hypersecretion of FSH in monkeys American Journal of Physiology 243 E387-E397

Goodman AL and Rone JD (1987) Thyroid angiogenesis: endotheliotropic chemoattractant activity from rat thyroid cells in culture Endocrinology $\mathbf{1 2 1}$ 2131-2140

Gospodarowicz D, Cheng J, Lui BM, Baird A, Esch F and Bohlen P (1985) Corpus luteum angiogenic factor is related to fibroblast growth factor Endocrinology $1172283-2291$

Jones RE (1978) Control of follicle selection. In The Vertebrate Ovary pp 763 788 Ed. RE Jones. Plenum Press, NY

Katz E, Goodman AL, Garcia J and Rone JD (1992) Evidence for the production of a nonsteroidal angiogenic factor by human granulosa cells in cuiture Fertility and Sterility 57 107-112

Koos RD (1986) Stimulation of endothelial cell proliferation by rat granulosa cell-conditioned media Endocrinology 119 481-489

Koos RD and LeMaire WJ (1983) Evidence for an angiogenic factor in rat follicles. In Factors Regulating Ovarian Function pp 191-195 Eds GS Greenwald and PF Terranova. Raven Press, NY

Kranzfelder D, Korr H, Mestwerdt W and Maurer-Schultze B (1984) Follicle growth in the ovary of the rabbit after ovulation-inducing application of human chorionic gonadotropin Cell Tissue Research 238 611-620

Lobb DK and Dorrington JH (1987) Human granulosa and thecal cells secrete distinct protein profiles Fertility and Sterility 48 243-246

Makris A, Ryan KJ, Yasumizu T, Hill CL and Zetter BR (1984) The nonluteal porcine ovary as a source of angiogenic activity Endocrinology 15 1672-1677

Mills TM and Gerardot RJ (1984) Dissociation of copulation from ovulation in pregnant rabbits Biology of Reproduction 30 1243-1252

Moor RM and Seamark RF (1986) Cell signaling, permeability and microvasculatory changes during antral follicle development in mammals Journal of Dairy Science 69 927-943
Neufeld G, Ferrara N, Schweigerer L, Mitchell R and Gospodarowicz D (1987) Bovine granulosa cells produce basic fibroblast growth factor Endocrinology $121597-603$

Osteen KG and Mills TM (1980) Changes in the size, distribution and steroid content of rabbit ovarian follicles during early pseudopregnancy Biology of Reproduction 22 1040-1046

Phillips HS, Hains J, Leung DW and Ferrara N (1990) Vascular endothelial growth factor is expressed in rat corpus luteum Endocrinology 127 965-967

Redmer DA, Rone JD and Goodman AL (1985a) Evidence for a nonsteroidal angiotrophic factor from the primate corpus luteum: stimulation of endothelial cell migration in vitro Proceedings of the Society for Experimental Biology and Medicine 179 136-140

Redmer DA, Rone JD and Goodman AL (1985b) Detection of angiotrophic activity from primate dominant follicle Proceeding of the 67th Annual Meeting Endocrine Society, Abstract 151

Redmer DA, Grazul AT, Kirsch JD and Reynolds LP (1988) Angiogenic activity of bovine corpora lutea at several stages of luteal development Joumal of Reproduction and Fertility $\mathbf{8 2} 627-634$

Redmer DA, Kirsch JD and Reynolds LP (1991) Production of mitogenic factors by cell types of bovine large estrogen-active and estrogen-inactive follicles journal of Animal Science $69237-245$

Richards JS (1980) Maturation of ovarian follicles: actions and interactions of pituitary and ovarian hormones on follicular cell differentiation Physiological Reviews $6051-89$

Rone JD and Goodman AL (1987) Heterogeneity of rabbit aortic endothelial cells in primary culture Proceedings of the Society for Experimental Biology and Medicine 184 495-503

Rone JD and Goodman AL (1990) Preliminary characterization of angiogenic activity in rat luteal cell conditioned media Endocrinology 127 2821-2828

Sato $E$, Ishibashi $T$ and Koide SS (1982) Inducement of blood vessel formation by ovarian extracts from mice injected with gonadotropins Experientia $\mathbf{3 8}$ 1248-1249

Sato E, Tanaka T, Takeya T, Miyamoto H and Koide SS (1991) Ovarian glycosaminoglycans potentiate angiogenic activity of epidermal growth factor in mice Endocrinology 128 2402-2406

Setty SL and Mills TM (1987) The effects of progesterone on follicular growth in the rabbit ovary Biology of Reproduction 36 1247-1252

Skinner MK, Lobb D and Dorrington JH (1987) Ovarian thecal/interstitial cells produce an epidermal growth factor-like substance Endocrinology 121 1892-1899

Taraska T, Reynolds LP and Redmer DA (1989) In vitro secretion of angiogenic activity by ovine follicles. In Growth Factors and the Ovary pp 267-272 Ed. AN Hirshfield. Plenum Press, NY

Zeleznik AJ, Schuler HM and Reichert Jr LE (1981) Gonadotropin-binding sites in the rhesus monkey ovary: role of the vasculature in the selective distribution of human chorionic gonadotropin to the preovulatory follicle Endocrinology 109 356-362 